\title{
Partitioning of melt energy and meltwater fluxes in the ablation zone of the west Greenland ice sheet
}

\author{
M. van den Broeke, P. Smeets, J. Ettema, C. van der Veen, R. van de Wal, and J. Oerlemans \\ Utrecht University, Institute for Marine and Atmospheric research (IMAU) P.O. Box 80005, 3508 TA \\ Utrecht, The Netherlands \\ Received: 2 July 2008 - Published in The Cryosphere Discuss.: 21 August 2008 \\ Revised: 21 October 2008 - Accepted: 31 October 2008 - Published: 8 December 2008
}

\begin{abstract}
We present four years (August 2003-August 2007) of surface mass balance data from the ablation zone of the west Greenland ice sheet along the $67^{\circ} \mathrm{N}$ latitude circle. Sonic height rangers and automatic weather stations continuously measured accumulation/ablation and near-surface climate at distances of 6,38 and $88 \mathrm{~km}$ from the ice sheet margin at elevations of 490, 1020 and $1520 \mathrm{~m}$ a.s.l. Using a melt model and reasonable assumptions about snow density and percolation characteristics, these data are used to quantify the partitioning of energy and mass fluxes during melt episodes. The lowest site receives very little winter accumulation, and ice melting is nearly continuous in June, July and August. Due to the lack of snow accumulation, little refreezing occurs and virtually all melt energy is invested in runoff. Higher up the ice sheet, the ice sheet surface freezes up during the night, making summer melting intermittent. At the intermediate site, refreezing in snow consumes about $10 \%$ of the melt energy, increasing to $40 \%$ at the highest site. The sum of these effects is that total melt and runoff increase exponentially towards the ice sheet margin, each time doubling between the stations. At the two lower sites, we estimate that radiation penetration causes $20-30 \%$ of the ice melt to occur below the surface.
\end{abstract}

\section{Introduction}

With a potential sea level rise of $7.3 \mathrm{~m}$, the Greenland ice sheet (GrIS) is the largest source of fresh water in the Northern Hemisphere (Bamber et al., 2001). Large uncertainties remain in the present and future balance state of the GrIS

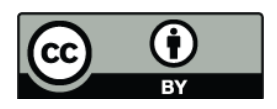

Correspondence to: M. van den Broeke (broeke@phys.uu.nl)
(Gregory et al., 2004; Parizek and Alley, 2004) and its contribution to sea level change (Cazenave, 2006; Lemke et al., 2007). Modelling the present-day and future balance state of the GrIS is complicated by our limited knowledge of the surface mass balance, being the sum of accumulation in the ice sheet interior and melting and subsequent runoff at the margins. Part of the meltwater produced at the surface refreezes in the firn, but how much is still a matter of debate (Pfeffer et al., 1991; Janssens and Huybrechts, 2000; Bougamont et al., 2007). Moreover, the ablation zone, where gradients are largest and where recent changes in marine terminating glaciers have been the most pronounced (Zwally et al., 2002; Krabill et al., 2004; Joughin et al., 2008; Van de Wal et al., 2008 ) is only $1 \mathrm{~km}$ (along southeast GrIS) to $100 \mathrm{~km}$ (along southwest GrIS) wide, which requires a very high horizontal model resolution.

Idealized mass balance models do have the required resolution, but need prescribed radiation and temperature fields (Bøggild et al., 1994; Braithwaite, 1995; Van de Wal and Oerlemans, 1997). Output of meteorological models, on the other hand, includes the necessary physics but requires downscaling to obtain the desired resolution (Wild et al., 2003; Bougamont et al., 2005; Hanna et al., 2006). When coupled to a physical snow model, regional atmosphere models have the right mix of high resolution and realistic physics to study the present-day mass balance of the GrIS (Cassano et al., 2001; Dethloff et al., 2002; Box et al., 2006; Fettweis, 2007).

Validation of these models requires detailed observations from the ablation zone. Ablation stakes are measured only once a year, so they provide no insight in the temporal variability during the melt season. To resolve this, automatic weather stations (AWS) are increasingly being used (Steffen and Box, 2001). The K-transect, a stake array along the $67^{\circ}$

Published by Copernicus Publications on behalf of the European Geosciences Union. 


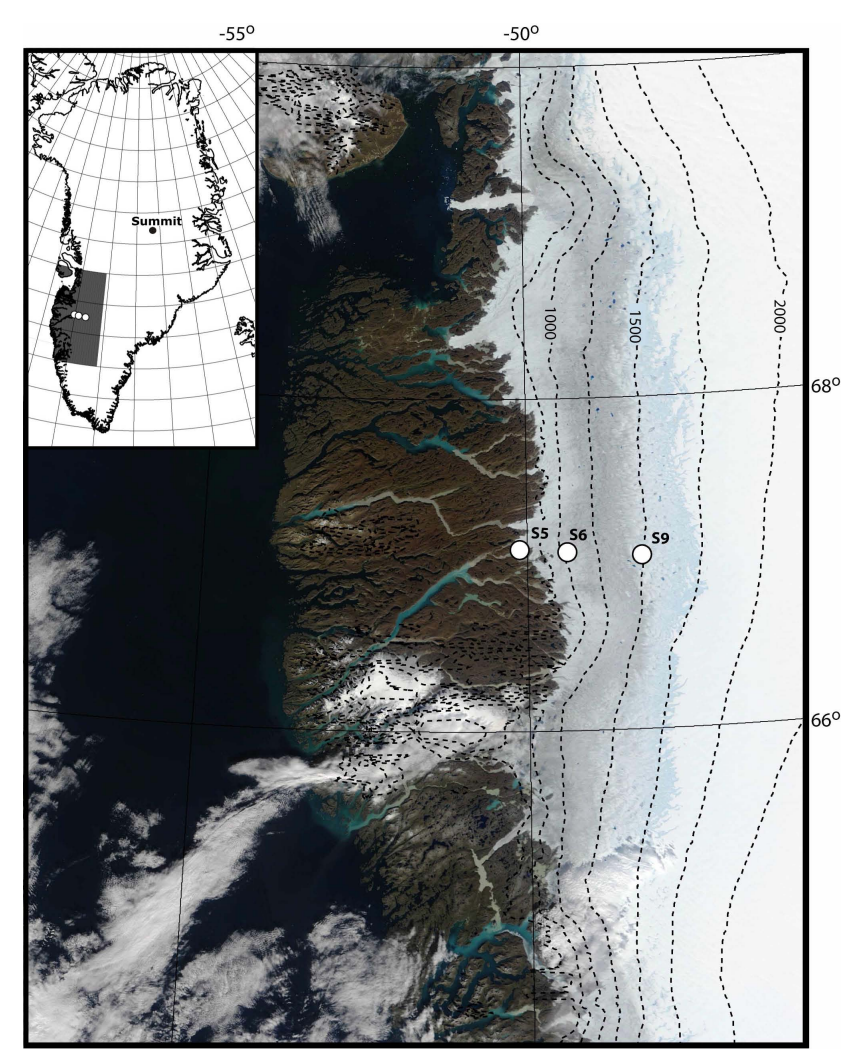

Fig. 1. MODIS scene of west Greenland (23 August 2006) with AWS locations (white dots) and ice sheet elevation contours (dashed lines, height interval $250 \mathrm{~m}$, from Bamber et al., 2001).

latitude circle in southwest Greenland, was set up during the Greenland Ice Margin Experiment in 1990 (GIMEX-90, Oerlemans and Vugts, 1993) and currently represents the longest mass balance time series of its kind in Greenland (Van de Wal et al., 2005). In August 2003, three AWS with sonic height rangers were installed along the K-transect at 6,38 and $88 \mathrm{~km}$ from the ice sheet margin at elevations of 490 , 1020 and $1520 \mathrm{~m}$ a.s.l. Here we present the first four years of data from the sonic height rangers, and compare them to stake measurements as well as output of a melt model forced by data of the AWS. In Sect. 2 we describe the experimental set-up and data treatment methods, followed by a description of the melt model in Sect. 3, results and discussion in Sect. 4 and a summary and conclusions in Sect. 5.

\section{Observations}

\subsection{Field area and AWS description}

Figure 1 is a MODIS scene of the field area on $23 \mathrm{Au}-$ gust 2006. At this time of year the ablation season in West Greenland is coming to an end. The image shows the bare ice zone (white to greyish, between 500-1500 m a.s.1.), the superimposed ice zone (milky blue, $1500-1750 \mathrm{~m}$ a.s.l.)

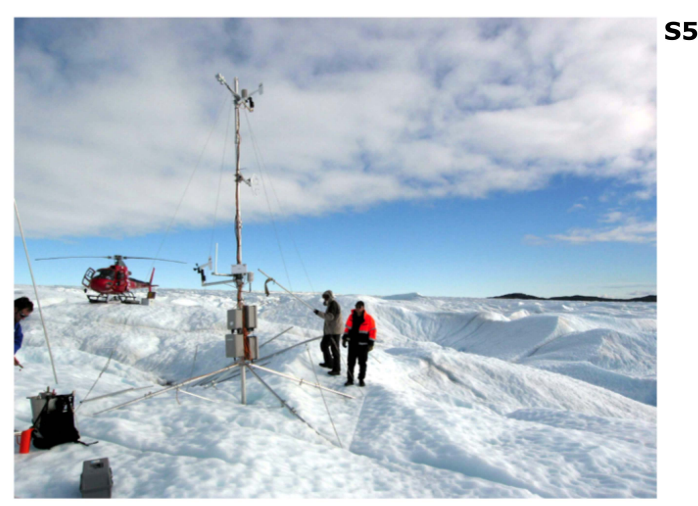

S6

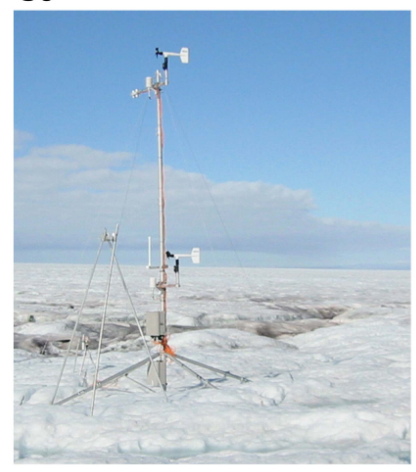

S5

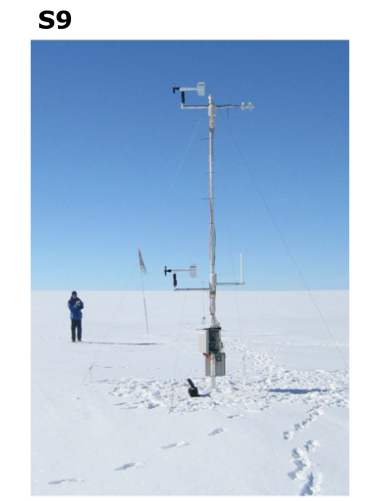

Fig. 2. Images of AWS surroundings at S5 (photo taken $27 \mathrm{Au}-$ gust 2006), S6 and S9 (photo's 26 August 2006). Photos by Paul Smeets (UU/IMAU).

and the snow-covered percolation zone $(1750 \mathrm{~m}$ a.s.l. and higher). The AWS sites are named S5 (490 $\mathrm{m}$ a.s.1.), S6 (1020 m a.s.1.) and S9 (1520 ma.s.1.) and are part of the Ktransect, the mass balance stake array in southwest Greenland that extends from the ice margin to $1800 \mathrm{~m}$ a.s.l. (Van de Wal et al., 2005). Figure 2 shows the AWS and their surroundings. The surface at S5 is very irregular with $2-3 \mathrm{~m}$ high ice hills, while at $S 9$ the surface is much smoother and covered by a layer of fresh snow.

The sonic height rangers are attached to three stakes that are fixed relative to the ice/snow surface (Fig. 2); they resolve surface height changes in excess of $1-2 \mathrm{~cm}$. The AWS stand freely on the ice and are allowed to sink with the ablating surface. They measure wind speed/direction, temperature, relative humidity at nominal heights of 2 and $6 \mathrm{~m}$ and the full radiation balance at a nominal height of $6 \mathrm{~m}$. Air pressure is measured in the electronics enclosures box. Sensor specifications are listed in Table 1. Most variables are sampled at 6-min intervals (instantaneous, except for wind speed, cumulative) after which one-hour averages are stored in a Campbell CR10 datalogger with separate memory module. Ice/snow temperatures are not being continuously measured at the AWS sites, but a single measurements effort was 
Table 1. AWS sensor specifications. EADT=Estimated Accuracy for Daily Totals.

\begin{tabular}{llll}
\hline AWS sensors & Type & Range & Accuracy \\
\hline Air pressure & Vaisala PTB101B & 600 to $1060 \mathrm{hPa}$ & $4 \mathrm{hPa}$ \\
Air temperature & Vaisala HMP35AC & -80 to $+56^{\circ} \mathrm{C}$ & $0.3^{\circ} \mathrm{C}$ \\
Relative humidity & Vaisala HMP35AC & 0 to $100 \%$ & $2 \%(\mathrm{RH}<90 \%)$ \\
& & & $3 \%(\mathrm{RH}>90 \%)$ \\
Wind speed & Young 05103 & 0 to $60 \mathrm{~m} \mathrm{~s}^{-1}$ & $0.3 \mathrm{~m} \mathrm{~s}^{-1}$ \\
Wind direction & Young 05103 & 0 to $360^{\circ}$ & $3^{\circ}$ \\
Pyranometer & Kipp en Zonen CM3 & 305 to $2800 \mathrm{~nm}$ & EADT+/ $-10 \%$ \\
Pyrradiometer & Kipp en Zonen CG3 & 5000 to $50000 \mathrm{~nm}$ & EADT+/-10\% \\
Snow height & Campbell SR50 & 0.5 to $10 \mathrm{~m}$ & $0.01 \mathrm{~m}$ or $0.4 \%$ \\
\hline
\end{tabular}

done in 2000 when $10 \mathrm{~m}$ ice temperatures were measured at all sites along the K-transect. These data have been used to initialize the model.

\subsection{AWS data treatment}

Before the AWS data are fed into the melt model, they are quality controlled and corrected if necessary. Problems associated with ill-functioning sensors could be adequately addressed by post-processing; radiation and temperature/relative humidity corrections have been described in detail in Smeets and Van den Broeke (2008a) and Van den Broeke et al. (2008a, b). The depth of the snow layer covering the ice was reconstructed using a combination of surface height and albedo observations. Individual missing snow height data were linearly interpolated; this may cause unrealistic hourly ablation rates, which are of no concern for this paper. Surface height data at S6 are missing from midJanuary to mid-June 2005; we used melt energy from the energy balance model (see next section) in combination with an assumed snow density of $500 \mathrm{~kg} \mathrm{~m}^{-3}$ to reconstruct the date and magnitude of the maximum snow depth.

\section{Melt model}

\subsection{Surface energy balance}

The AWS data serve as input for a melt model that calculates the atmospheric and subsurface energy fluxes and simulates the ablation of snow and ice. The amount of melt at the surface is determined by the surface energy balance (SEB), which for a snow/ice surface can be written as:

$$
\begin{aligned}
M & =\mathrm{SW} \downarrow+\mathrm{SW} \uparrow+\mathrm{LW} \downarrow+\mathrm{LW} \uparrow+\mathrm{SHF}+\mathrm{LHF}+G_{s} \\
& =\mathrm{SW}_{\text {net }}+\mathrm{LW}_{\text {net }}+\mathrm{SHF}+\mathrm{LHF}+G_{s} \\
& =R_{\text {net }}+\mathrm{SHF}+\mathrm{LHF}+G_{s}
\end{aligned}
$$

where $M$ is melt energy $(M=0$ if surface temperature $\left.T_{S}<273.15 \mathrm{~K}\right), \mathrm{SW} \downarrow$ and $\mathrm{SW} \uparrow$ are downward and reflected shortwave radiation fluxes, LW $\downarrow$ and $\mathrm{LW} \uparrow$ are downward and emitted longwave radiation fluxes, SHF and LHF are the turbulent fluxes of sensible and latent heat and $\mathrm{G}_{s}$ is the subsurface conductive heat flux at the surface. All terms are defined positive when directed towards the surface.

Equation (1) describes the SEB of a "skin" layer without heat capacity, the temperature of which reacts instantaneously to a change in energy input. By assuming Eq. (1) to be valid, we neglect subsurface penetration of SW radiation. This is justified for snow, but not for ice, in which SW radiation is known to penetrate to considerable depths (Brandt and Warren, 1993). To mimic this process, a SW radiation penetration routine is activated in the subsurface model when no snow cover is present (Sect. 3.3). The amount of SW radiation that is absorbed below the surface is then deducted from $\mathrm{SW}_{\text {net }}$ in Eq. (1).

\subsection{Energy fluxes from the atmosphere}

The atmospheric part of the melt model treats the radiation and turbulent fluxes. $\mathrm{SW}_{\text {net }}$ and $\mathrm{LW} \downarrow$ are used as direct input from (corrected) observations. SHF and LHF are calculated using the "bulk" method, a robust vertically integrated version of the flux-profile relations that uses single-level wind speed, temperature and humidity measurements. Van den Broeke (1996) and Van den Broeke et al. (2008b) validated the bulk method for Greenland AWS data and discussed the relation of the turbulent fluxes to the local surface layer climate. The $6 \mathrm{~m}$ AWS level values are used for the flux calculations to minimize the uncertainty in the measurement level displacement distance due to the rough surface.

Surface temperature $T_{s}$ follows from solving Eq. (1) and the bulk fluxes. Because the turbulent fluxes strongly depend on $T_{S}$ the solution is found in an iterative procedure. Surface specific humidity is calculated by assuming the snow/ice surface to be saturated. Also required for the turbulent flux calculations is the surface roughness for momentum $z_{0}$. In the Greenland ablation zone, $z_{0}$ is highly variable in space and time (Smeets and Van den Broeke, 2008a). Because wind speed, temperature and humidity with respect to water vapor are measured at nominal heights of 2 and $6 \mathrm{~m}$, the 
Table 2. AWS topographic and climate characteristics.

\begin{tabular}{|c|c|c|c|}
\hline & S5 & S6 & S9 \\
\hline \multicolumn{4}{|l|}{ Location (August 2006) } \\
\hline Latitude $(\mathrm{N})$ & $67^{\circ} 06^{\prime}$ & $67^{\circ} 05^{\prime}$ & $67^{\circ} 03^{\prime}$ \\
\hline Longitude (W) & $50^{\circ} 07^{\prime}$ & $49^{\circ} 23^{\prime}$ & $48^{\circ} 14^{\prime}$ \\
\hline Elevation (m a.s.1.) & 490 & 1020 & 1520 \\
\hline Distance from ice edge $(\mathrm{km})$ & 6 & 38 & 88 \\
\hline \multicolumn{4}{|c|}{ Period of operation used for this paper } \\
\hline Start of observation & 28 Aug 2003 & 1 Sep 2003 & 1 Sep 2003 \\
\hline End of observation & 27 Aug 2007 & 31 Aug 2007 & 31 Aug 2007 \\
\hline \multicolumn{4}{|l|}{ Annual mean climate variables } \\
\hline Mass balance (m w.e.) & -3.6 & -1.5 & $\sim 0$ \\
\hline Pressure $(\mathrm{hPa})$ & 950 & 887 & 835 \\
\hline $2 \mathrm{~m}$ temperature $(\mathrm{K})$ & 267.7 & 263.4 & 260.6 \\
\hline $2 \mathrm{~m}$ relative humidity $(\%)$ & 75 & 87 & 90 \\
\hline $2 \mathrm{~m}$ specific humidity $\left(\mathrm{g} \mathrm{kg}^{-1}\right)$ & 2.4 & 2.2 & 1.9 \\
\hline $10 \mathrm{~m}$ wind speed $\left(\mathrm{m} \mathrm{s}^{-1}\right)$ & 5.0 & 6.4 & 7.3 \\
\hline End of summer $z_{0}(\mathrm{~m})$ & $2 \times 10^{-2}$ & $1 \times 10^{-2}$ & $1 \times 10^{-5}$ \\
\hline
\end{tabular}

gradients can be used to calculate the surface roughness for momentum, $z_{0}$, using similarity theory. To reduce the uncertainties associated with $z_{0}$ determination form only two measurements levels, but still obtain temporal information, we adopted a 20-day running mean of $z_{0}$. It is shown in Van den Broeke et al. (2008b) that at S5 and S6, $z_{0}$ reaches its maximum value in late August $(\sim 0.01 \mathrm{~m})$ and the minimum value in March $\left(\sim 10^{-4} \mathrm{~m}\right)$. The scalar roughness lengths for heat $\left(z_{h}\right)$ and moisture $\left(z_{q}\right)$ are calculated using the expressions of Andreas (1987) and for very rough ice surfaces we adopted the adjustments proposed by Smeets and Van den Broeke (2008b).

\subsection{Subsurface processes}

The temperature evolution of the snow/ice layers is calculated by solving the one-dimensional heat-transfer equation on grid levels spaced $0.04 \mathrm{~m}$ apart down to a depth of $20 \mathrm{~m}$. The model takes into account the extinction of SW radiation in the upper ice layers if no snow is present at the surface, and heating by refreezing of liquid water:

$$
\begin{gathered}
\rho_{i} c_{p} \frac{\partial T_{i}}{\partial t}=-\frac{\partial G_{i}}{\partial z}-\frac{\partial Q}{\partial z}+S \\
=\frac{\partial}{\partial z}\left(k_{i} \frac{\partial T_{i}}{\partial z}\right)-\frac{\partial Q}{\partial z}+S
\end{gathered}
$$

where fluxes towards the surface are defined positive and $\mathrm{z}$ is positive downward; $\rho_{i}$ is the density of the snow/ice layer, $c_{p}$ its specific heat, $G_{i}$ the conductive heat flux, $Q$ the subsurface shortwave radiation flux, $T_{i}$ the layer temperature, $k_{i}$ the thermal conductivity, which is calculated as a function of density according to Anderson (1976), and $S$ is a source/sink term that accounts for refreezing/melting. The snow/ice temperature profile is initialized using measured ice temperature data. Below $20 \mathrm{~m}$ depth, $G_{i}$ is assumed to vanish. The surface value, $G_{s}$, is extrapolated upwards from values at 2 and $6 \mathrm{~cm}$ depth.

When ice is at the surface, the model of Brandt and Warren (1993) is used to calculate the subsurface shortwave radiation flux $(Q)$. The radiation grid has $1 \mathrm{~mm}$ resolution to a depth of $5 \mathrm{~m}$, after which radiative heating is interpolated to the coarser $G_{i}$ grid. Radiation transport is based on Mie scattering in a medium of perfectly stacked spherical particles with $2.5 \mathrm{~mm}$ diameter combined with the two-stream approach of Schlatter (1972). The model uses 118 wavelength bands to account for the highly wavelength-dependent absorption properties of ice.

In the case of surface melting, meltwater is assumed to runoff instantaneously when the surface consists of ice; when a snowpack is present, meltwater is allowed to percolate to deeper layers, be retained in the snow matrix or refreeze, following Greuell and Konzelmann (1994). When liquid water reaches the ice horizon, it is assumed to run off. Because divergence of $Q$ acts as a local heat source, sub-surface melting may occur in the upper ice layers. The associated meltwater is assumed to leave the ice matrix instantaneously as runoff. The model does not treat snow densification, as we have no information on whether changes in the snow depth are caused by melting, settling or other processes. Rather, snow depth is prescribed from observations and snow density is kept constant at $500 \mathrm{~kg} \mathrm{~m}^{-3}$. This value was obtained by assuming the modelled snowmelt energy to be correct and combining 


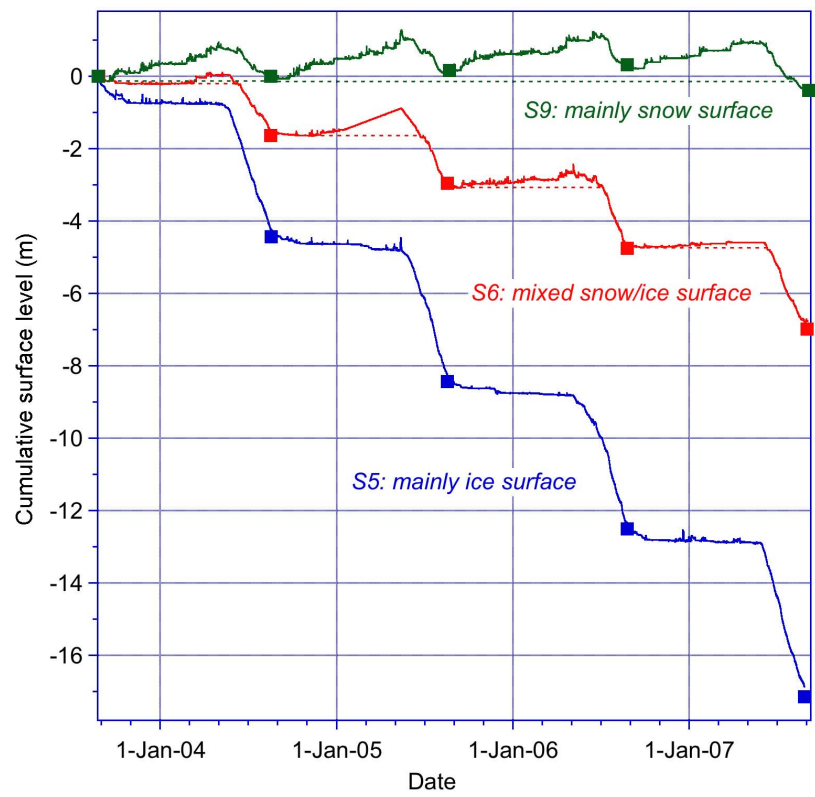

Fig. 3. Reconstruction of snow depth and ice surface lowering using albedo and sonic height ranger data at S5 (blue line), S6 (red line) and S9 (green line). The dashed line indicates the reconstructed ice horizon. Surface height data at S6 are missing from mid-January to mid-June 2005, and have been reconstructed using output of the energy balance model (see text).

this with observed snow depth changes in spring. Prescribing snow depth in the model ensures that snowmelt stops and ice melt starts at the correct time.

\subsection{Calculation of melt energy $M$}

With the AWS data at hand, there are two ways to detect melting and calculate $M$. One method is to prescribe a threshold value in "observed" surface temperature $T_{s}$ (i.e. derived from $\mathrm{LW} \uparrow$ assuming the surface to have unit emissivity) to detect melt, and sum the individual SEB components in Eq. (1) to calculate $M$. The problem with this approach is that the measurement of $\mathrm{LW} \uparrow$ leads to uncertainties in $T_{s}$, so that an arbitrary threshold value of $T_{s}$ smaller than $273.15 \mathrm{~K}$ must be chosen to represent melting conditions. If all values of $T_{S}<273.15 \mathrm{~K}$ were simply ignored for the melt calculation, $M$ would be systematically underestimated.

A more objective method to detect and quantify melt is to cast Eq. (1) in a form that only has $T_{s}$ as variable, i.e. writing the expressions for SHF, LHF, $G$ and $\mathrm{LW} \uparrow$ in terms of $T_{s}$ and setting $M=0$. The resulting equation is then solved for $T_{S}$ using the method of bisection in a $15 \mathrm{~K}$ search space around the value of $T_{S}$ from the previous timestep. If $T_{S}$ exceeds the melting point, it is reset to $273.15 \mathrm{~K}$ and this value is then substituted in Eq. (1), which directly yields $M$. This way of working assumes a closed energy balance and differs from Van den Broeke et al. (2008a, b), who did not need a value

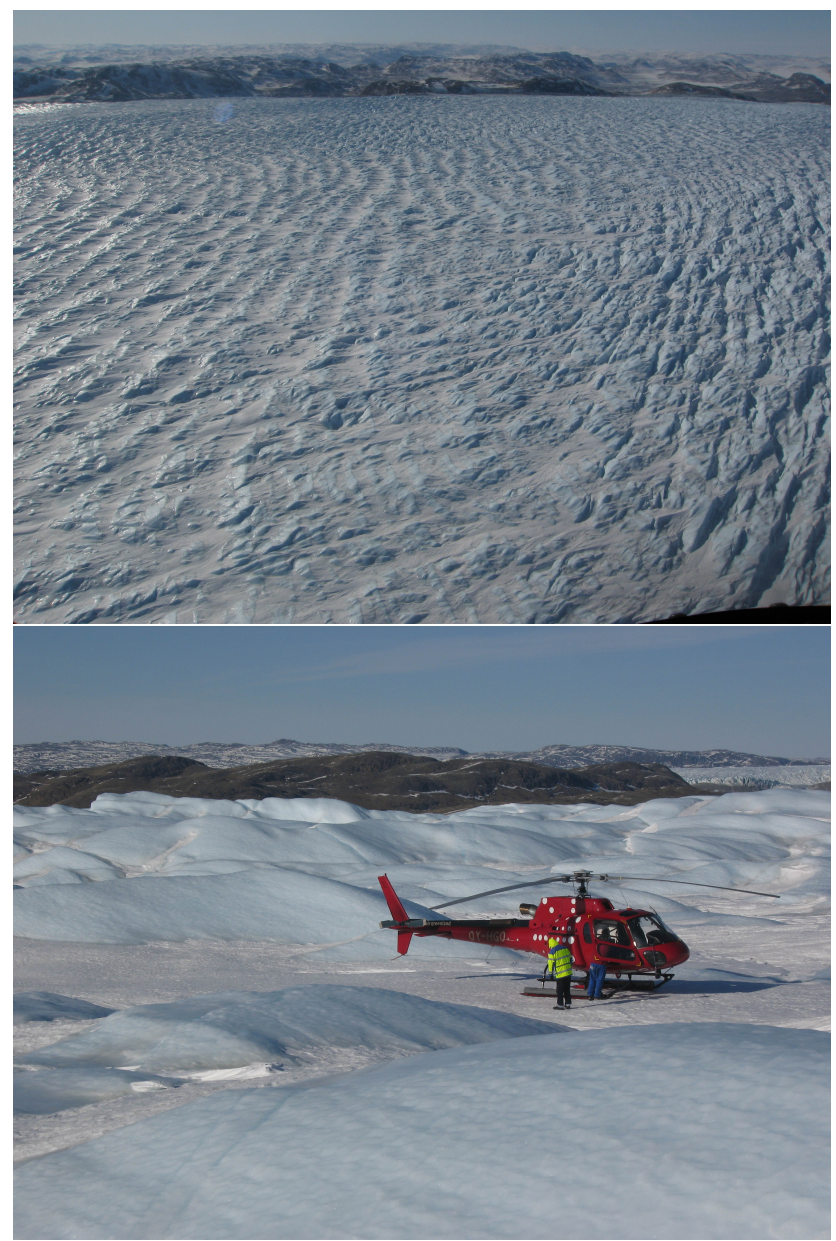

Fig. 4. Aerial view (a) and ground view (b) of the surroundings of S5 at the end of winter (April 2008) but before the start of the melting season. Photos by Paul Smeets (UU/IMAU).

for $M$ and therefore used "observed" $T_{s}$, which is the most direct way to obtain radiation and turbulence climate at the AWS sites. It should be noted that $T_{s}$ is fixed under melting conditions and that the calculated melt rate is not affected by uncertainties in $T_{s}$. Further verification of the method used here can be obtained by comparing the modelled ice melt with that observed with the sonic height ranger, see next section.

\section{Results and discussion}

\subsection{Reconstructed snow depth}

Figure 3 shows the cumulative height of the ice and snow surface as reconstructed from the sonic height ranger. The annual stake measurements (squares) nicely confirm the sonic height ranger data. Over this four-year period, the net annual surface mass balance is about zero at $\mathrm{S} 9$, and negative by about 1.8 and $4.1 \mathrm{~m}$ of ice at S6 and S5, respectively. 


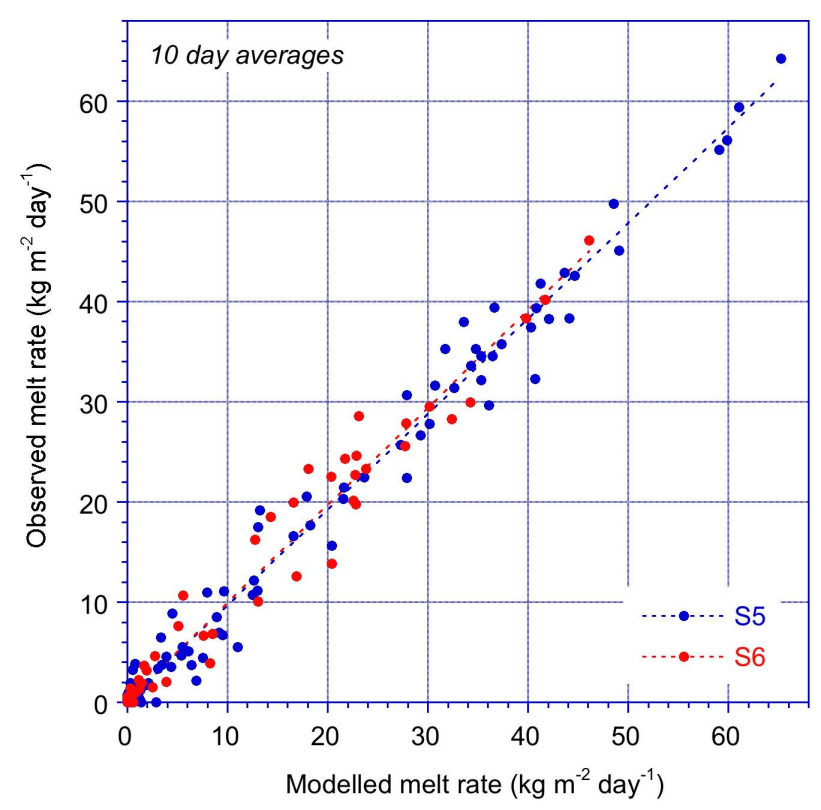

Fig. 5. Measured ice lowering as a function of modelled melt energy, for 10 day periods at S5 and S6. Dashed lines are the linear regressions.

A remarkable and important feature is that the winter snow cover at S5 is very shallow $(<0.2 \mathrm{~m})$ and only episodically present. Apparently, precipitated snow is blown into gullies and crevasses or eroded/sublimated from the surface. Because at S5, the sonic height ranger stands on a small ice hill, it will not register snow that collects in the surrounding gullies.

Figure 4a shows an aerial view of the accumulation pattern close to S5 in April 2008, at the end of winter and before melting started. It shows that a shallow snow cover is present in the gullies surrounding the ice hummocks. The image taken on the ground (Fig. 4b) confirms that the ice hummocks remain snow-free while the surrounding gullies are filled with a shallow snow layer. The lack of a continuous snow cover on the tundra hills in the background suggests that winter accumulation is indeed small in this area, and certainly less than sites higher up along the K-transect. As a result of the low winter accumulation, ice melting at S5 starts as early as May and continues well into September.

With $20-70 \mathrm{~cm}$ of snow, winter accumulation at S6 is more significant. At this site, this winter snow typically melts away in June, followed by ice ablation in July and August. In 2006/2007, winter accumulation was especially small at S6. Followed by the warm summer of 2007, this resulted in record ice melting at this site. For S9, which is situated close to the equilibrium line, we assumed that (superimposed) ice was at the surface at the beginning of the observation period in August 2003, following the warm 2003 summer. After
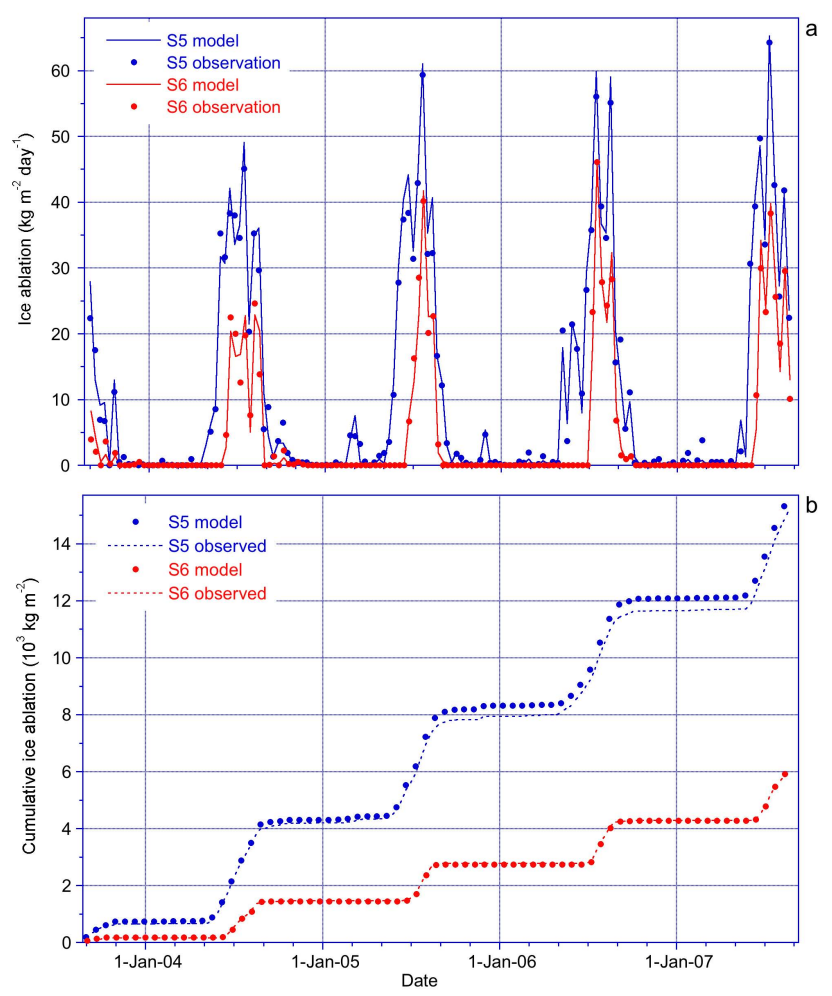

Fig. 6. (a) ice ablation summed over 10-day periods in $\mathrm{kg} \mathrm{m}^{-2}$ per day, modelled (solid lines) and observed (dots), using an ice density of $910 \mathrm{~kg} \mathrm{~m}^{-3}$, for S5 and S6; (b) modelled (dots) and observed (dashed lines) cumulative ice ablation at S5 and S6.

that, the glacier ice horizon was not reached again until $\mathrm{Au}-$ gust 2007, when a small amount of ice melted. As a result, ablation at $\mathrm{S} 9$ consists predominantly of snowmelt with occasional melt of (superimposed) ice. From the above, it is clear that the three sites represent very different ablation regimes.

\subsection{Validation of modelled ice ablation}

Validation of the melt model is limited to periods of ice melting at S5 and S6, as hardly any ice melted at S9, and the density of the melted snow is not known. Hourly or even daily ice melt rates cannot be used as validation, as the sonic height ranger has an accuracy of 1-2 cm while typical daily ice melt rates are only marginally larger. To improve the signal to noise ratio, we use 10-day observed cumulative ice melt rates, obtained by performing a linear regression on hourly surface height values over consecutive 10-day periods. Figure 5 compares measured to modelled melt rate (expressed in $\mathrm{kg} \mathrm{m}^{-2} \mathrm{day}^{-1}$ ) at S5 (blue dots) and S6 (red dots). To convert observed ice ablation to mass, we used an ice density of $910 \mathrm{~kg} \mathrm{~m}^{-3}$ in line with laboratory measurements performed on ice samples from the GrIS ablation zone. The correlation is very high for both sites $(r=0.99)$ and the regression slopes equal to unity within the uncertainty range. 


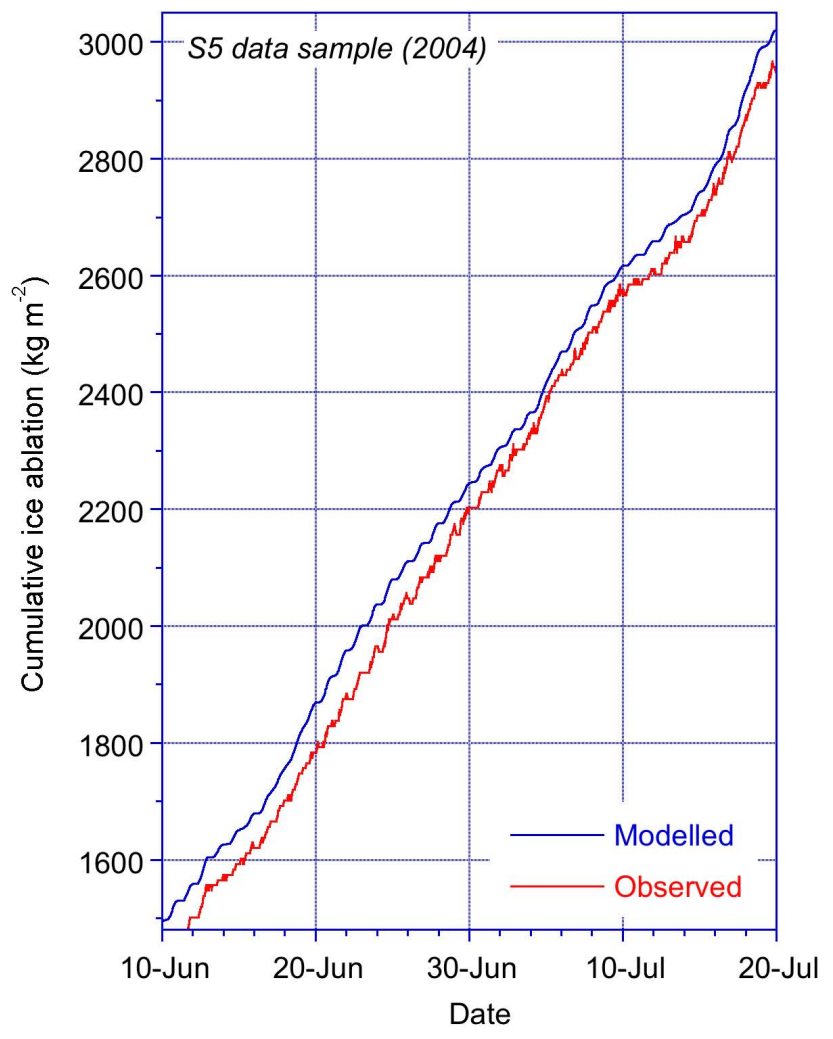

Fig. 7. Detail of observed (red) and modelled (blue) hourly cumulative ice ablation at S5, summer 2004, assuming an ice density of $910 \mathrm{~kg} \mathrm{~m}^{-3}$ for the observations.

The largest relative errors are found for 10-day periods with low melt. The reason for this may be that for these low melt amounts $(<10 \mathrm{~cm})$, the measurement uncertainty becomes relatively large and dominates the comparison.

Figure 6 shows time series of (a) observed and modelled 10-day melt rates and (b) cumulative ice ablation at S5 and S6. Maximum observed 10-day average melt rates are close to $60 \mathrm{~kg} \mathrm{~m}^{-2}$ day $^{-1}$ at S5, extremes that are well captured by the model. The model also reproduces non-summer melt events at S5 (Fig. 6a). Apart from a small $(<10 \%)$ melt overestimate at S5 in 2005, the cumulative melt (Fig. 6b) is also well modelled, confirming the absence of systematic errors.

To qualitatively assess the performance of the melt model at daily and sub-daily time scales, Fig. 7 compares modelled and observed ice melt at hourly resolution at S5 for 40 days in the summer of 2004. The daily cycle in melting is at the limit of what the sonic height ranger can resolve, but is nonetheless clearly visible in the observations and faithfully reproduced by the model. Episodes with enhanced melt rates, during which the daily cycle becomes small and strong melting continues during the night (e.g. around 5 and 18 July), are well captured, as are episodes with a reduced melt rate (1112 July), reflecting cold air outbreaks and cloudy conditions.

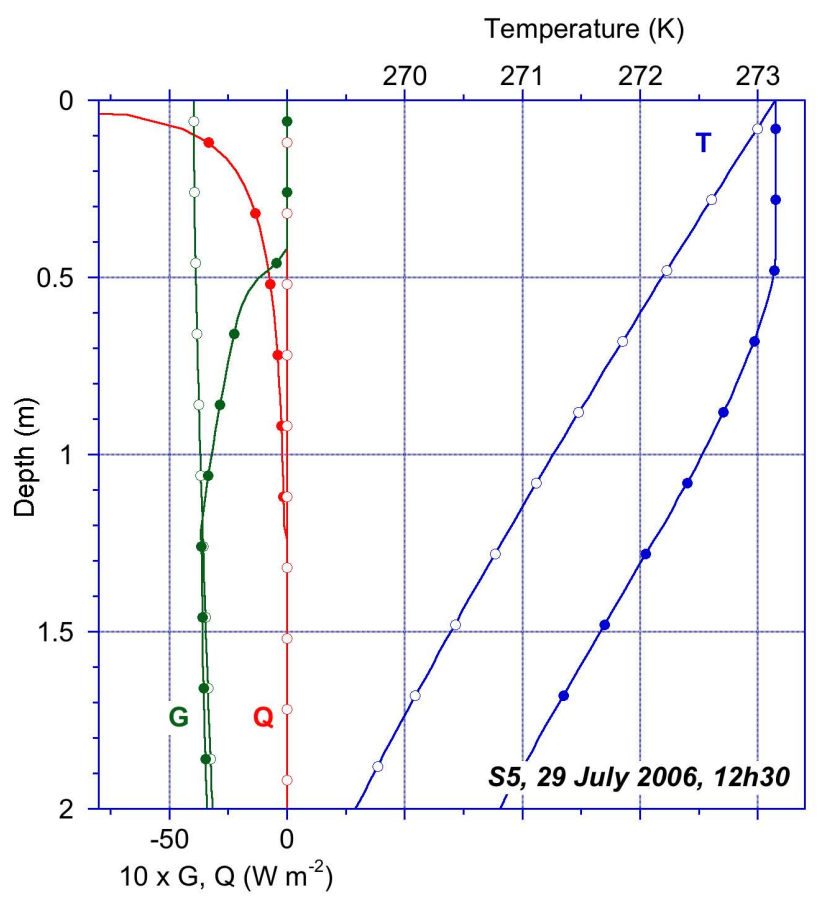

Fig. 8. Example profiles of subsurface heat flux (G, green and multiplied by 10 for clarity), penetrating shortwave radiation (Q, red) and temperature (T, blue) for 29 July 2006, 12:30 GMT, with $\mathrm{SW}_{\text {net }}$ was $245 \mathrm{~W} \mathrm{~m}^{-2}$. Open symbols: without radiation penetration; solid symbols: with radiation penetration.

\subsection{Effect of radiation penetration}

Figure 8 shows modelled vertical profiles in the ice at S5 of subsurface heat flux ( $G$, multiplied by 10 for clarity), penetrating shortwave radiation $(Q)$ and temperature $(T)$ with and without shortwave radiation penetration. These profiles are for 29 July 2006, 12:30 GMT, at which time no snow was present and $\mathrm{SW}_{\text {net }}$ was $245 \mathrm{~W} \mathrm{~m}^{-2}$. If radiation penetration is not allowed in the model (open symbols in Fig. 8), all shortwave radiation is absorbed at the surface and invested in melting there. In the absence of heat sources in the ice, only the surface is at the melting point, below which the temperature relaxes towards the deep ice temperature. With this temperature profile, $G_{s}$ extracts about $4 \mathrm{~W} \mathrm{~m}^{-2}$ of heat from the surface at the expense of melting.

When radiation penetration is allowed (solid symbols in Fig. 8), part of $\mathrm{SW}_{\text {net }}$ is absorbed below the surface and its divergence acts as a local heat source. As a result, the ice is melting down to a depth of $0.45 \mathrm{~m}$, in good agreement with measurements at ETH camp in 1990 and 1991, some $260 \mathrm{~km}$ to the north (Greuell and Konzelmann, 1994). Below that depth, no melting occurs but $Q$ is still nonzero: this heat is used to warm the deeper ice layers. This heat loss is partly compensated by the increased $G_{S}$ that equals zero in the isothermal melting layer. As a result, the total melt 

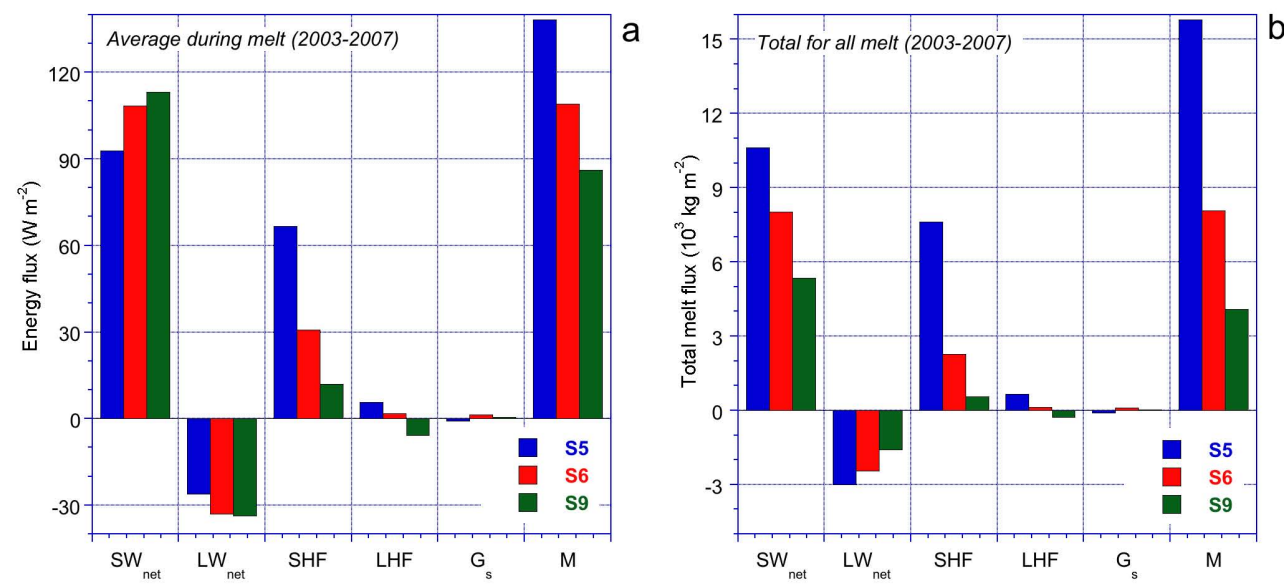

Fig. 9. (a) Average magnitude of surface energy balance components under melting conditions at S5 (blue bars), S6 (red bars) and S9 (green bars); (b) total melted ice mass over four years, expressed in $\mathrm{kg} \mathrm{m}^{-2}$, due to the various components of the surface energy balance at $\mathrm{S} 5$ (blue bars), S6 (red bars) and S9 (green bars).

energy is only slightly smaller than the case without radiation penetration. Note that subsurface melting decreases the ice density, but because the amount of $\mathrm{SW}_{\text {net }}$ absorbed at the surface decreases accordingly, surface lowering does not accelerate and a direct comparison of modelled ice melt with observations from the sonic height ranger remains meaningful.

\subsection{Energy flux partitioning during melt}

In this section, model output is used to partition the energy fluxes in Eq. (1) during melting conditions (Fig. 9). Melting of snow or ice occurs during $30 \%, 20 \%$ and $12 \%$ of the time at S5, S6 and S9, respectively. $1 \%, 6 \%$ and $12 \%$ of the time this constitutes snow melt, i.e. almost none at S5 and nearly all of the time at S9. At all three sites, the largest energy source during melting is absorbed shortwave radiation $\left(\mathrm{SW}_{\text {net }}\right)$, ranging between $90-110 \mathrm{~W} \mathrm{~m}^{-2}$ (Fig. 9a). The lower value of $\mathrm{SW}_{\text {net }}$ at $\mathrm{S} 5$ indicates that melt is less biased towards daytime, i.e. melt also regularly continues at low sun angles, as was visible in Fig. 7. With values of -25 to $-35 \mathrm{~W} \mathrm{~m}^{-2}$, net longwave radiation $\left(\mathrm{LW}_{\text {net }}\right)$ is a significant heat sink during melting conditions, especially in the higher ablation zone. Because $\mathrm{LW} \uparrow$ is fixed during melting, the differences in $\mathrm{LW}_{\text {net }}$ represent the effect of decreasing $\mathrm{LW} \downarrow$ towards higher elevations.

The sensible heat flux (SHF) represents a significant source of melt energy at $\mathrm{S} 5, \sim 65 \mathrm{~W} \mathrm{~m}^{-2}$, owing to persistent katabatic winds in combination with a rough ice surface and large surface to air temperature gradients under melting conditions. The latent heat flux (LHF) contributes to melt at S5 but acts as energy sink in the higher ablation zone, but the absolute values are small, $<10 \mathrm{~W} \mathrm{~m}^{-2}$. The subsurface heat flux $\left(G_{S}\right)$ is negligible during melting conditions, because radiation penetration causes the upper ice layers to be isothermal at $0^{\circ} \mathrm{C}$. On average, $M$ is largest at $\mathrm{S} 5,138 \mathrm{~W} \mathrm{~m}^{-2}$, mainly a result of the large SHF and limited LW heat loss. At S6 and S9, the contribution of SHF to the energy balance becomes small compared to $\mathrm{SW}_{\text {net }}$, in agreement with observations made by Henneken et al. (1994).

If melt duration is taken into account, we obtain the total melt amount for the four-year period (August 2003-August 2007), expressed in $\mathrm{kg} \mathrm{m}^{-2}$ (Fig. 8b). Note that total melt doubles going from $\mathrm{S} 9$ to $\mathrm{S} 6$, and again doubles from $\mathrm{S} 6$ to S5. This exponential increase can be ascribed to the rapidly increasing contribution of SHF towards the lower ablation zone in response to higher air temperatures and larger surface roughness in summer. At S5, where the melt season is longest, $\mathrm{SW}_{\text {net }}$ is responsible for total ice melt of $10500 \mathrm{~kg} \mathrm{~m}^{-2}$ and SHF of $7500 \mathrm{~kg} \mathrm{~m}^{-2}$, the latter representing $\sim 50 \%$ of the total.

\subsection{Mass flux partitioning}

In this study we focus on the partitioning of the meltwater flux. Rain is not detected by the AWS nor modelled, while sublimation constitutes a small mass loss in the ablation zone, on average $1.3 \%$ (S5), 1.0\% (S6) and 2.0\% (S9) of the total melt flux over this four-year period. Runoff represents meltwater that leaves the local hydrological system of the ice sheet. In our simple model, runoff has four components: 1) surface ice melt and subsequent runoff, 2) water vapour condensation on the ice surface and subsequent runoff, 3) internal ice melt and subsequent runoff and 4) runoff at the bottom of the snow pack. When ice is at the surface, all meltwater that is produced at or below the ice surface is assumed to run off instantaneously. When the surface consists of snow with (some of) the subsurface snow layers having a temperature below freezing, refreezing of meltwater will occur. This obviously reduces runoff, so that runoff equals total melt plus condensation minus refreezing. 
Figure 10 shows modelled meltwater fluxes, divided into snow and ice melt as well as in a refreezing and runoff component, cumulated over the four-year period. In the absence of significant winter accumulation at S5, nearly no refreezing occurs at this site and all melt energy is invested in ice melting and runoff (Fig. 10a). According to the model, about $23 \%$ of ice melt occurs below the surface. Cumulative runoff slightly exceeds total melt, as a result of water vapour condensation on the cold ice sheet in summer $(\mathrm{LHF}>0$, see Fig. 8). The condensation flux is so small, that it is not included in Fig. 10a.

At S6, $\sim 23 \%$ of the total melt energy is invested in snow melting (Fig. 10b), of which about $40 \%$ refreezes in the underlying snowpack. Over the four-year period, this reduces runoff to about $92 \%$ of the total meltwater production. For S6, the model predicts that about $30 \%$ of the ice melts below the surface, slightly more than S5 where part of the penetrated SW radiation is used to warm up the upper ice layers in the pre-melt season, in the absence of a snow cover.

At S9 (Fig. 10c) we assumed that the ice horizon was at the surface at the start of the model integration, i.e. at the end of the warm 2003 summer. Apart from a short period in September 2003, all summer melt energy in the subsequent three years is invested in melting of the previous winter snowpack. Only in 2007 did some ice melt at the end of summer at S9 (see also Fig. 3). According to the model, refreezing consumes about $1 / 3$ of the total melt energy at S9. Note the exceptional melt in 2007, where melt and runoff are greater than previous summers by a factor of 2 and 2.5, respectively. Anomalously sunny conditions accelerated snow melting in July and revealed the dark ice surface at the beginning of August. The difference with previous years is most pronounced at $\mathrm{S}$, where $\mathrm{SW}_{\text {net }}$ dominates the energy balance during melt (Fig. 9a).

\section{Summary and conclusions}

Four years of data (August 2003-August 2007) from automatic weather stations and sonic height rangers were fed into a melt model to quantify surface energy and meltwater fluxes in the ablation zone of the west Greenland ice sheet. Data were collected along the $67^{\circ}$ latitude circle at distances of 6,38 and $88 \mathrm{~km}$ from the ice sheet margin at elevations of 490, 1020 and $1520 \mathrm{~m}$ a.s.l. In the lower ablation zone, about half of the melt energy is provided by the turbulent sensible heat flux (SHF), the remainder by net shortwave radiation and latent heat exchange. The role of SHF decreases rapidly towards the high ablation zone, where net shortwave radiation becomes the sole term of importance during melting conditions. The large gradient in SHF accentuates melt gradients in the west Greenland ablation zone, with melt energy roughly doubling each $40 \mathrm{~km}$ when going from the equilibrium line towards the ice sheet margin.
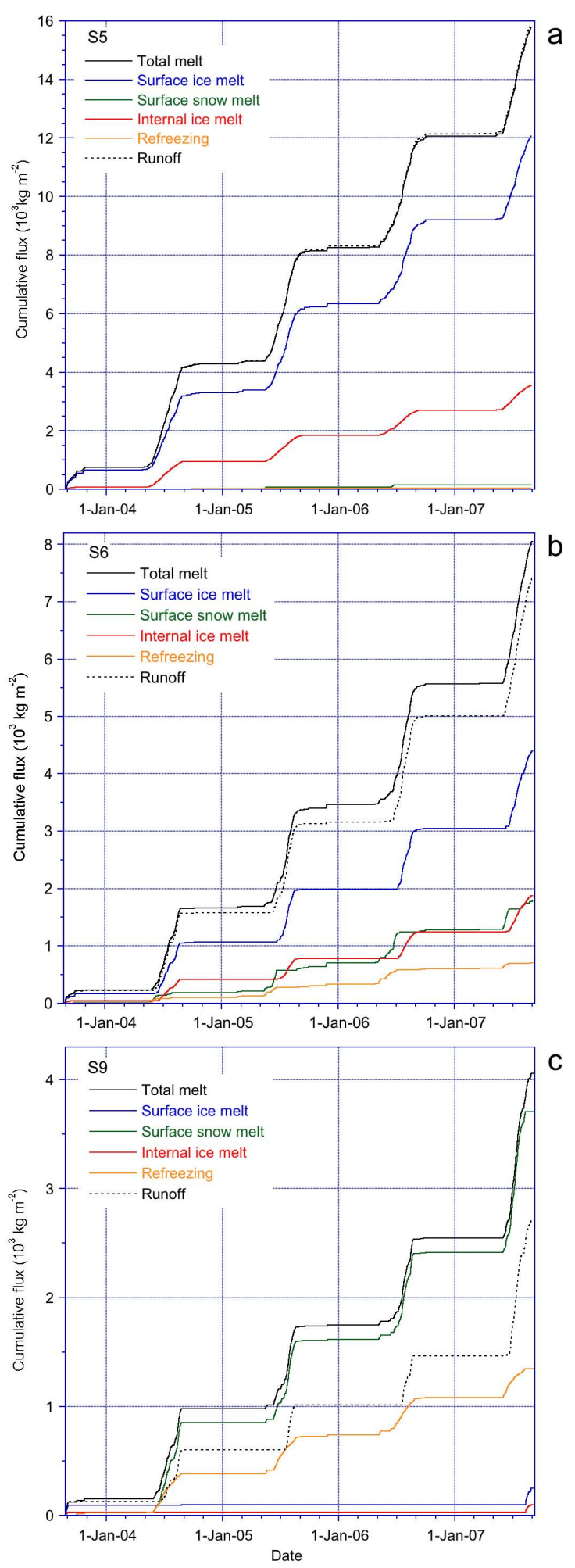

Fig. 10. Cumulative modelled melt in $\mathrm{kg} \mathrm{m}^{-2}$, at (a) S5, (b) S6 and (c) S9. A division is made between snow melt, surface ice melt and internal ice melt as well as between refreezing and runoff (see text). 
In the beginning of the melt season, part of the meltwater refreezes in the cold winter snowpack. In the absence of significant winter accumulation, refreezing is insignificant in the lower ablation zone, which exhibits continuous ice melting and runoff during June, July and August. In the middle ablation zone, winter accumulation amounts up to 20$70 \mathrm{~cm}$ of snow, and refreezing reduces runoff to slightly more than $90 \%$ of the total meltwater production. At the highest site, refreezing consumes one-third of the total melt energy. Horizontal runoff gradients thus exceed melt gradients in the west Greenland ablation zone. It is clear that in order to resolve these steep and nonlinear horizontal gradients, highresolution modelling is required.

Acknowledgements. We thank IMAU technicians Wim Boot, Henk Snellen and Marcel Portanger for technical support. Dirk van As, Jason Box and an anonymous reviewer are acknowledged for useful comments that helped to improve the paper. This work is funded by Utrecht University and the Netherlands Polar Program (NPP) of the Netherlands Organisation of Scientific Research, section Earth and Life Sciences (NWO/ALW).

Edited by: E. Hanna

\section{References}

Anderson, E. A.: A point energy and mass balance model of a snow cover, NOAA Technical report NWS19, 1976.

Andreas, E. L.: A theory for the scalar roughness and the scalar transfer coefficients over snow and sea ice, Boundary-Layer Meteorol., 38, 159-184, 1987.

Bamber, J. L., Ekholm, S., and Krabill, W. B.: A new, highresolution digital elevation model of Greenland fully validated with airborne altimeter data, J. Geophys. Res., 106, 6733-6745, 2001.

Bøggild, C. E., Reeh, N., and Oerter, H.: Modelling ablation and mass-balance sensitivity to climate change of Storstrømmen, northeast Greenland, Glob. Planet. Change, 9, 79-90, 1994.

Bougamont, M., Bamber, J. L., and Greuell, W.: A surface mass balance model for the Greenland Ice Sheet, J. Geophys. Res., 110, F04018, doi:10.1029/2005JF000348, 2005.

Bougamont, M., Bamber, J. L., Ridley, J. K., Gladstone, R. M., Greuell, W. Hanna, E., Payne, A. J., and Rutt, I.: Impact of model physics on estimating the surface mass balance of the Greenland ice sheet, Geophys. Res. Lett., 34, L17501, doi:10.1029/2007GL030700, 2007.

Box, J. E., Bromwich, D. H., Veenhuis, B. A., Bai, L-S, Stroeve, J. C., Rogers, J. C., Steffen, K., Haran, T., and Wang, S.-H: Greenland ice sheet surface mass balance variability (1988-2004) from calibrated Polar MM5 output, J. Climate, 19, 2783-2800, 2006.

Braithwaite, R. J.: Positive degree-day factors for ablation on the Greenland ice sheet studied by energy balance modelling, J. Glaciol., 41, 153-160, 1995.

Brandt, R. E. and Warren, S. G.: Solar heating rates and temperature profiles in Antarctic snow and ice, J. Glaciol., 39, 99-110, 1993.

Cassano, J. J., Box, J. E., Bromwich, D. H., Li, L., and Steffen, K.: Evaluation of Polar MM5 simulations of Greenland's atmospheric circulation, J. Geophys. Res., 106, 33 867-33 890, 2001.
Cazenave, A.: How Fast Are the Ice Sheets Melting?, Science, 314, 1250-1252, 2006.

Dethloff, K., Schwager, M., Christensen, J. H., Kiilsholm, S., Rinke, A., Dorn, W., Jung-Rothenhäusler, F., Fischer, H., Kipfstuhl, S., and Miller, H.: Recent Greenland Accumulation Estimated from Regional Climate model simulations and ice core analysis, J. Climate, 15, 2821-2832, 2002.

Fettweis, X.: Reconstruction of the 1979-2006 Greenland ice sheet surface mass balance using the regional climate model MAR, The Cryosphere, 1, 21-40, 2007.

Gregory, J. M., Huybrechts, P., and Raper, S.: Threatened loss of the Greenland ice sheet, Nature, 428, 616, doi:10.1038/428616a, 2004.

Greuell, W. G. and Konzelmann, T.: Numerical modelling of the energy balance and the englacial temperature of the Greenland Ice Sheet: calculations for the ETH-Camp location (West Greenland, 1155 m a.s.1.), Glob. Planet. Change, 9, 91-114, 1994.

Hanna, E., McConnell, J., Das, S. B., Cappelen, S. J., and Stephens, A.: Observed and modeled Greenland ice sheet snow accumulation, 1958-2003, and links with regional climate forcing, J. Clim., 19, 344-358, 2006.

Henneken, E. A. C., Bink, N. J., Vugts, H. F., Cannemeijer, F., and Meesters, A. G. C. A.: A case study of the daily energy balance near the equilibrium line on the Greenland ice sheet, Glob. Planet. Change, 9, 69-78, 1994.

Janssens, I. and Huybrechts, P.: The treatment of meltwater retention in mass-balance parameterizations of the Greenland ice sheet, Ann. Glaciol., 31, 133-140, 2000.

Joughin, I., Das, S. B., King, M. A., Smith, B. E., Howat, I. M. and Moon, T.:Seasonal speedup along the western flank of the Greenland ice sheet, Science, 320, 781-783, 2008.

Krabill, W., Hanna, E., Huybrechts, P., Abdalati, W., Cappelen, J., Csatho, B., Frederick, E., Manizade, S., Martin, C., Sonntag, J., Swift, R., Thomas, R., and Yungel, J.: Greenland Ice Sheet: Increased coastal thinning, Geophys. Res. Lett., 31, L24402, doi:10.1029/2004GL021533, 2004.

Lemke, P., Ren, J., Alley, R. B., Allison, I., Carrasco, J., Flato, G., Fujii, Y., Kaser, G., Mote, P., Thomas, R. H. and Zhang, T.: Observations: Changes in Snow, Ice and Frozen Ground, in: Climate Change 2007: The Physical Science Basis, Contribution of Working Group I to the Fourth Assessment Report of the Intergovernmental Panel on Climate Change, edited by: Solomon, S., Qin, D., Manning, M., Chen, Z., Marquis, M., Averyt, K. B., Tignor M., and Miller, H. L., Cambridge University Press, United Kingdom and New York, USA, 2007.

Oerlemans, J. and Vugts, H. F.: A Meteorological Experiment in the Melting Zone of the Greenland Ice Sheet, Bull. Am. Meteorol. Soc., 74, 355-365, 1993.

Parizek, B. R. and Alley, R. B.: Implications of increased Greenland surface melt under global-warming scenarios: Ice-sheet simulations, Quat. Sci. Rev. 23, 1013-1027, 2004.

Pfeffer, W. T., Meier, M. F., and Illangasekare, T. H.: Retention of Greenland runoff by refreezing: Implications for projected future sea-level change, J. Geophys. Res., 96, 22 117-22 124, 1991.

Schlatter, T. W.: The local surface energy balance and subsurface temperature regime in Antarctica, J. Appl. Meteorol., 11, 10481062, 1972.

Smeets, C. J. P. P. and Van den Broeke, M. R.: Temporal and spatial variation of momentum roughness length in the ablation zone of 
the Greenland ice sheet, Bound.-Lay. Meteorol., 128, 315-338, 2008a.

Smeets, C. J. P. P. and Van den Broeke, M. R.: Parameterizing scalar roughness over smooth and rough ice surfaces, Bound.-Lay. Meteorol., 128, 339-355, 2008b.

Steffen, K. and Box, J. E.: Surface climatology of the Greenland ice sheet: Greenland Climate Network 1995-1999, J. Geophys. Res., 106(D24), 33 951-33 964, 2001.

Van de Wal, R. S. W. and Oerlemans, J.: Modelling the short-term response of the Greenland ice sheet to global warming, Clim. Dynam., 13, 733-744, 1997.

Van de Wal, R. S. W., Greuell, W. Van den Broeke, M. R., Boot, W., Snellen, H., Reijmer C. H., and Oerlemans, J.: Mass balance measurements along a transect in West-Greenland over the period 1990-2003, Ann. Glaciol., 42, 311-316, 2005.

Van de Wal, R. S. W., Boot, W., Van den Broeke, M. R., Smeets, C. J. P. P., Reijmer, C. H., Donker, J. J. A., and Oerlemans, J.: Large and rapid melt-induced velocity changes in the ablation zone of the Greenland ice sheet, Science, 321, 111-113, doi:10.1126/science.1158540, 2008.
Van den Broeke, M. R.: Characteristics of the lower ablation zone of the west Greenland ice sheet for energy-balance modelling, Ann. Glaciol., 23, 160-166, 1996.

Van den Broeke, M. R., Smeets, C. J. P. P., Ettema, J., and KuipersMunneke, P.: Surface radiation balance in the ablation zone of the west Greenland ice sheet, J. Geophys. Res., 113, D13105, doi:10.1029/2007JD009283, 2008a.

Van den Broeke, M. R., Smeets, C. J. P. P. and Ettema, J.: Climate and turbulent exchange in the surface layer of the west Greenland ablation zone, Int. J. Climatol., in press 2008b.

Wild, M., Calanca, P., Scherrer, S. C., and Ohmura, A.: Effects of polar ice sheets on global sea level in highresolution greenhouse scenarios, J. Geophys. Res., 108(D5), 4165, doi:10.1029/2002JD002451, 2003.

Zwally, H. J., Abdalati, W., Herring, T., Larson, K. Saba, J., and Steffen, K.: Surface melt-induced acceleration of Greenland ice-sheet flow, Science, 297, 218-222, doi:10.1126/science.1072708, 2002. 